\title{
Marker assisted development and characterization of non-GM herbicide tolerant Near Isogenic Lines of a mega Basmati rice variety, "Pusa Basmati 1121"
}

\section{Nitasha Grover}

Indian Agricultural Research Institute Division of Genetics and Amity University

Aruna Kumar

Amity University Noida, UP

Ashutosh Kumar Yadav

Indian Agricultural Research Institute Division of Genetics

\section{Gopala Krishnan S.}

Indian Agricultural Research Institute Division of Genetics

\section{Ranjith Kumar Ellur}

Indian Agricultural Research Institute Division of Genetics

\section{Prolay Kumar Bhowmick}

Indian Agricultural Research Institute Division of Genetics

K.K. Vinod

Indian Agricultural Research Institute Division of Genetics

Haritha Bollinedi

Indian Agricultural Research Institute Division of Genetics

\section{Nagarajan}

Rice breeding and Genetics Research centre, IARI, Aduturai, Tamil Nadu

\section{Viswanthan}

Indian Agricultural Research Institute

Amitha Mithra V. Sevanthi

National Institute for Plant Biotechnology

Nagendra Kumar Singh

National Institute for Plant Biotechnology

Trilochan Mohapatra

Indian Council of Agricultural Research

Ashok Kumar Singh ( $\square$ aks_gene@yahoo.com )

ICAR-INDIAN AGRICULTURAL RESEARCH INSTITUTE https://orcid.org/0000-0002-9777-8163 
Keywords: DSR, Marker assisted backcross breeding, AHAS, herbicide tolerant, foreground and Background selection, grain and cooking quality, Basmati rice

Posted Date: June 2nd, 2020

DOI: https://doi.org/10.21203/rs.3.rs-32436/v1

License: (c) (1) This work is licensed under a Creative Commons Attribution 4.0 International License. Read Full License

Version of Record: A version of this preprint was published on September 15th, 2020. See the published version at https://doi.org/10.1186/s12284-020-00423-2. 


\section{Abstract \\ Background}

Direct-seeded rice (DSR) is a potential technology for sustainable rice farming as it saves water and labor. However, higher incidence of weed under DSR limits productivity. Therefore, there is a need to develop herbicide tolerant $(\mathrm{HT})$ rice varieties.

\section{Results}

We used marker assisted backcross breeding (MABB) to transfer a mutant allele of Acetohydroxy acid synthase $(A H A S)$ gene, which confers tolerance to imidazolinone group of herbicides from the donor parent (DP) "Robin" into the genetic background of an elite popular Basmati rice variety Pusa Basmati 1121 (PB 1121). Foreground selection was done using the AHAS gene linked Simple Sequence Repeat (SSR) marker RM6844 and background selection was performed using 112 genome-wide SSR markers polymorphic between PB 1121 and Robin. Phenotypic selection for agronomic, Basmati grain and cooking quality traits in each generation was carried out to improve the recovery of recurrent parent phenome (RPP). Finally, a set of $12 \mathrm{BC}_{4} \mathrm{~F}_{4}$ near isogenic lines (NILs), with recurrent parent genome (RPG) recovery ranging from 98.66 to $99.55 \%$ were developed and evaluated. PB 1121-HT NILs namely 1979-14-7-33-9910, 1979-14-7-33-99-15 and 1979-14-7-33-99-66 were found superior to PB 1121 in yield with comparable grain and cooking quality traits and herbicide tolerance similar to Robin.

\section{Conclusion}

Overall, the present study reports successful development of non-GM HT NILs in the genetic background of popular Basmati rice variety PB 1121 by introgression of mutated AHAS allele. This is the first report of the development of HT rice in India. Superior NILs are being evaluated in the national Basmati trials, the release of which is likely to provide a viable option for the adoption of DSR technology in Basmati rice cultivation.

\section{Background}

In South-East Asian countries, where rice is primarily cultivated by transplanting, DSR holds great promise as it is a potential water and labor saving technology, which offers the possibility of saving huge amount of water and labour needed for puddling and transplanting. However, DSR cultivation suffers from high weed infestation. Weeds pose a serious threat by competing with the crop for water, nutrients and light, thereby hampering productivity (Powles and Yu 2010). In India, upto 30\% of the total cost of rice cultivation goes in controlling weeds (Rao et al. 2015). It has been demonstrated that with effective weed management, the yields from DSR is widely comparable to transplanted rice (Pathak et al. 2011). The use of herbicides is the most effective and economical option to control weeds (Anderson et al. 1989). 
However, the herbicides that are safe and effective at minimal doses should be used to ensure environmental safety. Imidazolinone group of herbicides (imazapyr, imazapic, imazethapyr, imazamox, imazamethabenz and imazaquin etc.), control weeds by inhibiting the enzyme acetohydroxyacid synthase (AHAS), also called acetolactate synthase (ALS). AHAS is a critical enzyme for the biosynthesis of branched-chain amino acids namely, leucine, isoleucine and valine in plants. These herbicides, also have low mammalian toxicity due to lack of AHAS gene (Tan et al. 2006; Piao et al. 2017). Due to the above benefits, the herbicides of imidazolinone group are most widely used for weed control in crops like soybean, groundnut etc., which possess natural tolerance to these herbicides. However, the crops like rice, maize, wheat, oilseed rape and sunflower etc. are highly sensitive to imidazolinones. Several variants of AHAS genes conferring imidazolinone tolerance have been developed through mutagenesis and selection in different crops and commercialized as Clearfield ${ }^{\circledR}$ crops since 1992. Imidazolinone herbicides control a broad spectrum of grass and broadleaf weeds in imidazolinone-tolerant crops, including weeds that are closely related to the crop itself and some key parasitic weeds (Tan et al. 2005).

Here, we report the transfer of mutant allele of $A H A S$ gene conferring herbicide tolerance from Robin into a mega Basmati rice variety, PB 1121, through MABB and assessment of PB 1121 NILs for agronomic, grain and cooking quality performance in addition to herbicide tolerance.

\section{Material And Methods}

\section{Plant materials}

In this study, we used the herbicide tolerant rice mutant Robin as donor and a mega-Basmati rice variety, PB 1121 as the recurrent parent (RP) for the transfer of HT trait. The mutant Robin was developed from an upland rice variety Nagina 22 (N22) through induced mutagenesis using ethyl methane sulfonate (EMS) (Shoba et al. 2017). PB 1121, developed by our group at ICAR-Indian Agricultural Research Institute (IARI), New Delhi, is a Basmati rice variety par excellence in grain and cooking quality with an exceptionally high cooked kernel length $(22 \mathrm{~mm})$ and elongation ratio of $>2.5$. This variety is currently grown on approximately 1.2 million ha area (60 percent of the Basmati area in India) and contributes annually 3.41 billion USD to foreign exchange earnings through the export of Basmati rice (Singh et al. 2018).

\section{MABB Strategy For Development Of HT Lines}

PB 1121 and mutant Robin were first evaluated for their tolerance to the herbicide "Imazethapyr" at the dose of $2.5 \mathrm{ml} /$ litre. The $\mathrm{F}_{1}$ seeds were produced by crossing PB 1121 as female and Robin as male and the hybridity of the $\mathrm{F}_{1}$ plants was tested using the SSR marker RM6844 linked with $A H A S$ gene, The $\mathrm{F}_{1} \mathrm{~S}$ were designated as Pusa 1979 and single $F_{1}$ was backcrossed with $P B 1121$ to generate $B C_{1} F_{1}$ seeds. One $\mathrm{BC}_{1} \mathrm{~F}_{1}$ plant with the highest recovery of RPG and recurrent parent phenome (RPP) was backcrossed to $\mathrm{PB} 1121$ to generate the $\mathrm{BC}_{2} \mathrm{~F}_{1}$ seeds. A similar strategy was employed till $\mathrm{BC}_{4} \mathrm{~F}_{1}$ generation, wherein in each of the generations, the plant heterozygous for the mutant $A H A S$ allele along with maximum recovery 
for RPG and RPP were identified. The superior $\mathrm{BC}_{4} \mathrm{~F}_{1}$ plants were advanced to $\mathrm{BC}_{4} \mathrm{~F}_{2}$ generation and plants homozygous for the mutant $A H A S$ gene were identified. Further, the selected $\mathrm{BC}_{4} \mathrm{~F}_{2}$ plants were advanced to $\mathrm{BC}_{4} \mathrm{~F}_{4}$ generation via pedigree-based phenotypic selection (Fig. 1).

\section{Molecular Analysis}

Total genomic DNA from leaf tissues was extracted using Cetyl Trimethyl Ammonium Bromide (CTAB) method (Doyle 1991). The PCR reaction of a total $10 \mu$ /volume was set up which included, $25-30 \mathrm{ng}$ of template DNA, 5 pmol each of the forward and reverse primers and $2 X$ red dye PCR master mix (Genei Laboratories Pvt. Ltd., Bangalore). The program of PCR amplification consisted of initial denaturation at $95^{\circ} \mathrm{C}$ for $5 \mathrm{~min} ; 35$ cycles of denaturation at $95^{\circ} \mathrm{C}$ for $40 \mathrm{~s}$, annealing at $58^{\circ} \mathrm{C}$ for $40 \mathrm{~s}$, extension at $72{ }^{\circ} \mathrm{C}$ for1 min; and a final extension at $72{ }^{\circ} \mathrm{C}$ for $10 \mathrm{~min}$. The amplified products were resolved on $3.5 \%$ Metaphor $^{\text {TM }}$ Agarose gel mixed with $0.1 \mathrm{mg} / \mathrm{ml}$ ethidium bromide. The amplicons were visualized on ultraviolet trans-illuminator (Gel Doc ${ }^{\mathrm{TM}}+$ Imager, Bio- Rad Laboratories Inc., U.S.A).

\section{Foreground And Background Selection}

Foreground selection for the identification of plants carrying the mutant $A H A S$ allele was carried out using SSR marker RM6844 linked with AHAS gene at a distance of $1.2 \mathrm{cM}$ in chromosome 2(Shoba et al. 2017), primer details are given in Table S1. For background selection, the primer sequence of genome-wide SSR markers was fetched from the rice marker database of Gramene (http://www.gramene.org). A total of 856 SSR markers were used to identify polymorphic markers between the parents PB 1121 and Robin, for use in background selection (Table S2). During the background selection in backcross generations, the homozygous and heterozygous plants for PB 1121 allele at each marker loci were counted separately. A reductionist strategy was considered for this, markers that were found to be homozygous for PB 1121 allele in a given generation were not included in subsequent generations for background selection. RPG recovery was estimated using the formula:

$R P G$ recovery $(\%)=\frac{\text { Number of markers homozygous for } R P \text { alleles }+(0.5 * \text { Number of markers heterozygous })}{\text { Total number of polymoprhic markers used for background selection }} X 100$

The RPG recovery was visualized using Graphical GenoTypes (GGT) Version 2.0 software (Van Berloo 1999). Based on molecular marker analysis, similarity of NILs to PB 1121 was computed using Jaccard's coefficient of similarity for generating a dendrogram following an unweighted pair group method with arithmetic mean (UPGMA). Further, for cluster analysis, NTSYS-PC-2.02f (Rohlf 1998) was used.

\section{Molecular Screening For Aroma Gene}

The NILs and the parents were also screened for the presence of badh2 gene, responsible for aroma in Basmati rice, using gene based marker ' $n k s b a d h 2$ ' (Amarawathi et al. 2008). Primer details are given in 
Table S3.

\section{Screening For Imazethapyr Tolerance}

Twelve HT-NILs of PB 1121 along with PB 1121 and Robin were planted in a randomized complete block design (RCBD) with three replications and sprayed with herbicide, Imazethapyr (commercially available as Pursuit $^{\mathrm{T}}$ ) @ concentration of $2.5 \mathrm{ml} /$ liter, after 10 days of transplanting. Another set of same experimental material was grown side by side and used as unsprayed control with manual weeding. Visual observation of herbicide tolerance of the HT-NILs was made on 15 days after spray as per the standard protocol in rice (Shoba et al. 2017).

\section{Evaluation Of Agro-morphological, Grain And Cooking Quality Parameters}

Agro-morphological evaluation of the HT-NILs and parents was done in RCBD with three replications following recommended agronomic practices. Data on the agro-morphological traits viz, days to $50 \%$ flowering (DFF), plant height (PH), number of productive tillers per plant (NPT), panicle length (PL), spikelet fertility (SF \%), thousand grain weight (TGW) were recorded on five plants taken at random from the two middle rows of each plot under both sprayed and unsprayed conditions. The plot yield was recorded in kilogram/hectare $(\mathrm{kg} / \mathrm{ha})$ from each replication. The data on grain and cooking quality traits such as hulling percentage (HUL\%), milling percentage (MIL\%), head rice recovery (HRR\%), kernel length before cooking (KLBC), kernel breadth before cooking (KBBC), kernel length after cooking (KLAC), kernel breadth after cooking (KBAC), kernel elongation ratio (ER), alkali spreading value (ASV) (Little et al.,1958) and aroma (Sood and Siddiq 1978) was recorded.

The statistical analysis of agro-morphological data was carried out using CropStat 7.2 (IRRI CropStat, 2014). Student's t-test was performed for statistical significance differences for yield between unsprayed and herbicide sprayed condition at $\mathrm{P} \leq 0.05$.

\section{Results}

\section{Development of PB 1121-NILs with herbicide tolerance}

The recurrent parent PB 1121 and donor Robin were validated for their tolerance to herbicide, Imazethapyr. PB 1121 was highly susceptible and exhibited complete mortality within 15-20 days of herbicide spray, while the donor Robin was highly tolerant to Imazethapyr (Fig. 2). MABB was adopted to transfer the HT trait into PB 1121 from Robin. $F_{1}$ plants obtained from the cross, PB 1121 and Robin were confirmed for their hybridity using AHAS gene linked SSR marker, RM6844. A true $\mathrm{F}_{1}$ plant was backcrossed to PB 1121 and $262 \mathrm{BC}_{1} \mathrm{~F}_{1}$ plants were generated. Of these, 128 plants were heterozygous for RM6844 with RPG recovery ranging from $70.98-80.35 \%$. A plant, Pusa 1979-14 with the highest RPG (80.35\%) and with a 
higher level of phenotypic similarity to PB 1121 was backcrossed and $188 \mathrm{BC}_{2} \mathrm{~F}_{1}$ plants were generated, of which 94 plants were heterozygous for foreground marker, RM6844 and the RPG recovery ranged from 81.25 to $92.85 \%$. The superior $\mathrm{BC}_{2} \mathrm{~F}_{1}$ plant was further backcrossed and $152 \mathrm{BC}_{3} \mathrm{~F}_{1}$ seeds were produced, out of which 73 plants were found to be heterozygous for the foreground marker and these plants were subjected to phenotypic evaluation for agro-morphological traits and background selection was done using 16 SSR markers remained heterozygous in the $B C_{2} F_{1}$ generation. The RPG recovery in the $B C_{3} F_{1}$ generation ranged from 93.30 to $95.08 \%$. One superior $\mathrm{BC}_{3} \mathrm{~F}_{1}$ plant, with maximum RPG (95.08\%) and relatively superior recovery for RPP was and backcrossed to generate $122 \mathrm{BC}_{4} \mathrm{~F}_{1}$ plants. A total of 58 plants were found to be heterozygous for RM6844 with RPG recovery range from 94.64 to $98.21 \%$. A plant with maximum RPG recovery (98.21\%) was selfed to produce BC4F2 population. Out of 384 BC4F2 plants, 88 plants were found to be homozygous for AHAS gene linked SSR marker RM6844.

The mutant AHAShomozygous plants were evaluated for grain and cooking quality traits and 40 superior plants were identified. These 40 progenies were further evaluated for yield and quality traits. Based on the family bulk yield and quality traits, twelve families were selected for further detailed evaluation. The RPG recovery of these families ranged from 98.66 to $99.55 \%$ with an average $99.10 \%$, some residual donor segments were observed in chromosome 8 and 11, whereas complete recovery was achieved in all other chromosomes (Fig. 3). All the PB 1121 HT-NILs clustered together with PB 1121 with an average similarity index (SI) of 0.9756. Among the HT-NILs, Pusa 1979-14-7-33-99-15 and Pusa 1979-14-7-33-99-66 showed maximum similarity with SI of 0.982 (Fig. 4).

Finally, selected $12 \mathrm{BC}_{4} \mathrm{~F}_{4}$ families were evaluated for Imazethapyr tolerance, agronomic, grain and cooking quality characters in the sprayed and unsprayed condition in a replicated trial.

\section{Evaluation of PB 1121- HT NILs for tolerance to herbicide Imazethapyr}

The PB 1121 HT-NILs along with parents, PB 1121 and Robin were screened for tolerance to herbicide Imazethapyr. All the NILs homozygous for the mutant AHAS allele exhibited complete tolerance to Imazethapyr. The level of herbicide tolerance in NILs was comparable to DP Robin. While, the RP PB 1121 possessing the wild type $A H A S$ gene did not survive after herbicide spray and showed complete mortality within 15 to 20 days of the Imazethapyr spray (Fig. 5).

\section{Evaluation of PB 1121 HT-NILs for agronomic, grain and cooking quality}

The mean performance of PB 1121 HT-NILs for yield, yield components and phenological traits, when grown under herbicide sprayed and unsprayed conditions were recorded. All the data from the sprayed condition and only yield data for unsprayed conditions are presented in Table 2. Under herbicide sprayed conditions, PB 1121 showed complete mortality within 15-20 days of spray, while the NILs showed normal growth and development (Fig. 6). Therefore, the yield and quality traits of NILs under sprayed condition were compared with the data of PB 1121 from unsprayed conditions. It was observed that NILs were at par with PB 1121 in yield, grain and cooking quality traits. NILs Pusa 1979-14-7-33-99-66 and Pusa 1979-14-7-33-99-143 were slightly taller in stature and the NILs Pusa 1979-14-7-33-99-15, Pusa 
1979-14-7-33-99-10 and Pusa 1979-14-7-33-99-66 were significantly superior in yield as compared to PB 1121 (Fig. 7 \& Table 2) which could be attributed to its higher spikelet fertility. There was no significant difference in the performance of NILs when compared under sprayed and unsprayed conditions (based on Student t-test) while PB 1121 was completely dead under sprayed condition.

Table 1

Number of plants generated and recurrent parent genome recovery in the backcross generations during marker aided introgression of mutant AHAS allele in PB 1121.

\begin{tabular}{|c|c|c|c|c|c|c|}
\hline Generation & $\begin{array}{l}\text { No. of } \\
\text { plants } \\
\text { generated }\end{array}$ & $\begin{array}{l}\text { No. of plants carrying } \\
\text { mutant } A H A S \text { allele in } \\
\text { heterozygous/ } \\
\text { homozygous state }\end{array}$ & $\begin{array}{l}\text { No. of } \\
\text { selected } \\
\text { plants/ } \\
\text { families }\end{array}$ & $\begin{array}{l}\text { Genome } \\
\text { recovery } \\
(\%)\end{array}$ & $\begin{array}{l}\text { Mean } \\
\text { Observed } \\
\text { RPG } \\
\text { Recovery } \\
(\%)\end{array}$ & $\begin{array}{l}\text { Expected } \\
\text { Average } \\
\text { Recovery } \\
\text { (\%) }\end{array}$ \\
\hline $\mathrm{F}_{1}$ & 15 & $15^{\#}$ & 1 & * & & \\
\hline $\mathrm{BC}_{1} \mathrm{~F}_{1}$ & 262 & $128^{\#}$ & 1 & $\begin{array}{l}70.98- \\
80.35\end{array}$ & 75.66 & 75 \\
\hline $\mathrm{BC}_{2} \mathrm{~F}_{1}$ & 188 & $94^{\#}$ & 1 & $\begin{array}{l}81.25- \\
92.85\end{array}$ & 87.05 & 87.5 \\
\hline $\mathrm{BC}_{3} \mathrm{~F}_{1}$ & 152 & $73^{\#}$ & 1 & $\begin{array}{l}93.30- \\
95.08\end{array}$ & 94.19 & 93.8 \\
\hline $\mathrm{BC}_{4} \mathrm{~F}_{1}$ & 122 & $58^{\#}$ & 1 & $\begin{array}{l}94.64- \\
98.21\end{array}$ & 96.42 & 96.9 \\
\hline $\mathrm{BC}_{4} \mathrm{~F}_{2}$ & 384 & $88^{\Delta}$ & 40 & * & - & - \\
\hline $\mathrm{BC}_{4} \mathrm{~F}_{3}$ & 40 & $40^{\Delta}$ & 12 & * & - & - \\
\hline $\mathrm{BC}_{4} \mathrm{~F}_{4}$ & 12 & $12^{\Delta}$ & 12 & $\begin{array}{l}98.66- \\
99.55\end{array}$ & 99.10 & - \\
\hline
\end{tabular}


Table 2

Agronomic performance of PB 1121 HT-NILs in comparison with the recurrent parent, PB 1121.

\begin{tabular}{|c|c|c|c|c|c|c|c|c|c|}
\hline \multirow[t]{2}{*}{ Genotype } & \multirow[t]{2}{*}{ DFF } & \multirow[t]{2}{*}{$\mathrm{PH}$} & \multirow[t]{2}{*}{ NPT } & \multirow[t]{2}{*}{ PL } & \multirow[t]{2}{*}{ SF\% } & \multirow[t]{2}{*}{ TGW } & \multicolumn{2}{|c|}{ YLD (kg/ha) } & \multirow[t]{2}{*}{ \%RPG } \\
\hline & & & & & & & USP & SP & \\
\hline $\begin{array}{l}\text { Pusa 1979- } \\
14-7-33-99- \\
8\end{array}$ & 106.0 & 123.15 & 19.30 & 27.89 & 88.20 & 28.87 & $\begin{array}{l}6701 \pm \\
274.40\end{array}$ & $\begin{array}{l}6517 \pm \\
311.34\end{array}$ & 98.66 \\
\hline $\begin{array}{l}\text { Pusa 1979- } \\
14-7-33-99- \\
10\end{array}$ & $109.0^{\star}$ & 122.45 & $20.60^{\star}$ & 28.40 & $92.70^{*}$ & 28.73 & $\begin{array}{l}7129 \pm \\
322.95^{*}\end{array}$ & $\begin{array}{l}7217 \pm \\
425.32^{*}\end{array}$ & 99.11 \\
\hline $\begin{array}{l}\text { Pusa 1979- } \\
14-7-33-99 \\
-15\end{array}$ & 106.0 & 131.53 & $20.20^{*}$ & 28.52 & $92.87^{*}$ & 28.93 & $\begin{array}{l}7310 \pm \\
382.05^{*}\end{array}$ & $\begin{array}{l}7417 \pm \\
467.53^{*}\end{array}$ & 99.55 \\
\hline $\begin{array}{l}\text { Pusa 1979- } \\
14-7-33-99- \\
34\end{array}$ & 107.0 & 126.25 & $19.70^{\star}$ & 29.28 & 87.53 & 27.99 & $\begin{array}{l}6673 \pm \\
497.09\end{array}$ & $\begin{array}{l}6255 \pm \\
350.39\end{array}$ & 99.11 \\
\hline $\begin{array}{l}\text { Pusa 1979- } \\
14-7-33-99- \\
56\end{array}$ & 106.5 & 128.85 & 17.20 & 27.56 & 87.75 & 28.88 & $\begin{array}{l}6836 \pm \\
359.89\end{array}$ & $\begin{array}{l}6582 \pm \\
300.78\end{array}$ & 99.11 \\
\hline $\begin{array}{l}\text { Pusa 1979- } \\
14-7-33-99- \\
66\end{array}$ & 106.5 & $136.85^{*}$ & $19.10^{*}$ & 29.29 & $92.74^{*}$ & 28.32 & $\begin{array}{l}7248 \pm \\
237.14^{*}\end{array}$ & $\begin{array}{l}7300 \pm \\
490.75^{*}\end{array}$ & 99.55 \\
\hline $\begin{array}{l}\text { Pusa 1979- } \\
14-7-33-99- \\
87\end{array}$ & 105.5 & 127.95 & 15.70 & 28.79 & 71.48 & 26.43 & $\begin{array}{l}4716 \pm \\
379.94\end{array}$ & $\begin{array}{l}4634 \pm \\
358.83\end{array}$ & 98.66 \\
\hline $\begin{array}{l}\text { Pusa 1979- } \\
14-7-33-99- \\
101\end{array}$ & 105.5 & 125.10 & 13.80 & 27.58 & 86.64 & 27.32 & $\begin{array}{l}5799 \pm \\
368.33\end{array}$ & $\begin{array}{l}5866 \pm \\
231.13\end{array}$ & 98.66 \\
\hline $\begin{array}{l}\text { Pusa 1979- } \\
14-7-33-99- \\
143\end{array}$ & 106.0 & $134.35^{*}$ & 15.50 & 28.56 & 84.80 & 28.30 & $\begin{array}{l}5832 \pm \\
586.79\end{array}$ & $\begin{array}{l}5559 \pm \\
265.96\end{array}$ & 98.66 \\
\hline $\begin{array}{l}\text { Pusa 1979- } \\
14-7-33-99- \\
166\end{array}$ & 107.0 & 133.47 & 17.30 & 27.73 & 89.11 & 28.54 & $\begin{array}{l}6910 \pm \\
426.37\end{array}$ & $\begin{array}{l}7017 \pm \\
522.41\end{array}$ & 99.11 \\
\hline $\begin{array}{l}\text { Pusa 1979- } \\
14-7-33-99- \\
182\end{array}$ & 107.5 & 124.85 & 16.90 & 27.33 & 87.11 & 27.92 & $\begin{array}{l}6502 \pm \\
346.16\end{array}$ & $\begin{array}{l}6506 \pm \\
316.17\end{array}$ & 98.66 \\
\hline
\end{tabular}

Data on DFF, PH, NPT, PL, SF\%, TGW presented is from Imazethpyr sprayed plots while the yield data (YLD) is presented for both unsprayed and herbicide sprayed plots. *Significant at 5\%; DFF: days to $50 \%$ flowering; PH: Plant height in cm ; NPT: Number of productive tillers; PL: Panicle length in cm; SF: Spikelet fertility percentage ; TGW: Thousand grain weight in grams (g), YLD: Plot yield in kg/ha; USP: Unsprayed condition; SP: herbicide (Imazethapyr) Sprayed condition; RPG: Recurrent Parent Genome; CD : Critical difference. "Data on DFF, PH, NPT, PL, SF\%, TGW for PB 1121 is from unsprayed plots for comparison, as PB 1121 did not survive under Imazethapyr spray. 


\begin{tabular}{|c|c|c|c|c|c|c|c|c|c|}
\hline \multirow[t]{2}{*}{ Genotype } & \multirow[t]{2}{*}{ DFF } & \multirow[t]{2}{*}{$\mathrm{PH}$} & \multirow[t]{2}{*}{ NPT } & \multirow[t]{2}{*}{$\mathrm{PL}$} & \multirow[t]{2}{*}{ SF\% } & \multirow[t]{2}{*}{ TGW } & \multicolumn{2}{|c|}{ YLD (kg/ha) } & \multirow[t]{2}{*}{ \%RPG } \\
\hline & & & & & & & USP & SP & \\
\hline $\begin{array}{l}\text { Pusa 1979- } \\
14-7-33-99- \\
226\end{array}$ & 106.0 & 126.00 & 16.80 & 27.48 & 88.14 & 27.90 & $\begin{array}{l}6599 \pm \\
368.68\end{array}$ & $\begin{array}{l}6547 \pm \\
282.89\end{array}$ & 99.11 \\
\hline PB $1121^{\#}$ & 106.0 & 125.58 & 16.06 & 29.81 & 86.10 & 28.92 & $\begin{array}{l}6250 \pm \\
369.38\end{array}$ & - & - \\
\hline CD (0.05) & 2.90 & 7.39 & 2.76 & 1.31 & 5.35 & 1.29 & 868.26 & 828.96 & - \\
\hline \multicolumn{10}{|c|}{$\begin{array}{l}\text { Data on DFF, PH, NPT, PL, SF\%, TGW presented is from Imazethpyr sprayed plots while the yield data } \\
\text { (YLD) is presented for both unsprayed and herbicide sprayed plots. *Significant at } 5 \% \text {; DFF: days to } \\
50 \% \text { flowering; PH: Plant height in cm ; NPT: Number of productive tillers; PL: Panicle length in cm; SF: } \\
\text { Spikelet fertility percentage ; TGW: Thousand grain weight in grams (g), YLD: Plot yield in kg/ha; USP: } \\
\text { Unsprayed condition; SP: herbicide (Imazethapyr) Sprayed condition; RPG: Recurrent Parent Genome; } \\
\text { CD : Critical difference. \#Data on DFF, PH, NPT, PL, SF\%, TGW for PB } 1121 \text { is from unsprayed plots for } \\
\text { comparison, as PB } 1121 \text { did not survive under Imazethapyr spray. }\end{array}$} \\
\hline
\end{tabular}

The mean performance of grain and cooking quality traits of the PB $1121 \mathrm{HT}-\mathrm{NILs}$ evaluated under sprayed condition is presented in Table 3. All the NILs possessed extra-long slender grain type with a very strong aroma, and ASV of 7.0, which was similar as that of PB 1121. Hulling percent (\%), milling (\%), and head rice recovery (\%), KLBC, KBBC, KBAC were comparable to PB 1121. Three NILs namely, Pusa 197914-7-33-99-15, Pusa 1979-14-7-33-99-10 and Pusa 1979-14-7-33-99-143 were found significantly superior for KLAC and elongation ratio as compared to PB 1121 (Table 3 \& Fig. 8) 
Table 3

Grain quality traits of PB 1121 HT-NILs in comparison to PB 1121.

\begin{tabular}{|c|c|c|c|c|c|c|c|c|c|c|}
\hline Genotype & HUL & MIL & HRR & KLBC & KBBC & KLAC & KBAC & $E / R$ & ASV & AROMA \\
\hline $\begin{array}{l}\text { Pusa } \\
1979-14-7- \\
33-99-8\end{array}$ & 77.77 & 67.46 & 55.96 & 8.77 & 1.61 & 18.54 & 2.28 & 2.11 & 7 & 3 \\
\hline $\begin{array}{l}\text { Pusa } \\
1979-14-7- \\
33-99-10\end{array}$ & 79.77 & 70.40 & 58.40 & 8.56 & 1.69 & $19.66^{*}$ & 2.36 & $2.29^{\star}$ & 7 & 3 \\
\hline $\begin{array}{l}\text { Pusa } \\
1979-14-7- \\
33-99- \\
15\end{array}$ & 78.92 & 68.33 & 54.83 & 8.71 & 1.68 & $19.69^{*}$ & 2.29 & $2.26^{\star}$ & 7 & 3 \\
\hline $\begin{array}{l}\text { Pusa } \\
1979-14-7- \\
33-99-34\end{array}$ & 76.70 & 66.73 & 55.13 & 8.83 & 1.67 & 19.35 & 2.32 & 2.18 & 7 & 3 \\
\hline $\begin{array}{l}\text { Pusa1979- } \\
14-7-33- \\
99-56\end{array}$ & 78.66 & 67.90 & 53.80 & 8.81 & 1.64 & 19.10 & 2.31 & 2.16 & 7 & 3 \\
\hline $\begin{array}{l}\text { Pusa } \\
1979-14-7- \\
33-99-66\end{array}$ & 78.23 & 68.33 & 56.05 & 8.72 & 1.63 & 18.97 & $2.48^{*}$ & 2.18 & 7 & 3 \\
\hline $\begin{array}{l}\text { Pusa } \\
1979-14-7- \\
33-99-87\end{array}$ & 77.50 & 69.23 & 55.36 & 8.62 & 1.69 & 18.46 & 2.31 & 2.14 & 7 & 3 \\
\hline $\begin{array}{l}\text { Pusa } \\
1979-14-7- \\
33-99-101\end{array}$ & 81.12 & 70.25 & 57.15 & 8.82 & 1.67 & 19.32 & 2.33 & 2.19 & 7 & 3 \\
\hline $\begin{array}{l}\text { Pusa } \\
1979-14-7- \\
33-99-143\end{array}$ & 78.60 & 69.65 & 56.67 & 8.97 & 1.74 & $20.29^{\star}$ & 2.32 & $2.26^{\star}$ & 7 & 3 \\
\hline $\begin{array}{l}\text { Pusa } \\
\text { 1979-14-7- } \\
33-99-166\end{array}$ & 77.07 & 67.89 & 54.09 & 8.75 & 1.67 & 18.88 & 2.31 & 2.16 & 7 & 3 \\
\hline $\begin{array}{l}\text { Pusa } \\
\text { 1979-14-7- } \\
33-99-182\end{array}$ & 77.76 & 66.64 & 54.95 & 8.73 & 1.64 & 19.32 & 2.31 & 2.21 & 7 & 3 \\
\hline
\end{tabular}

\footnotetext{
*Significant at 5\%; HUL: hulling recovery in percentage; MIL: milling recovery in percentage; HRR: head rice recovery in percentage; KLBC: kernel length before cooking in $\mathrm{mm}$; KBBC: kernel breadth before cooking in mm; KLAC: kernel length after cooking in mm; KBAC: kernel breadth after cooking in mm; E/R: kernel elongation ratio; ASV: alkali spreading value; AROMA: aroma score from panel test; "PB 1121 showed complete mortality after herbicide spray, the data of PB 1121 taken from the unsprayed area is presented for the purpose of comparison.
} 


\begin{tabular}{|c|c|c|c|c|c|c|c|c|c|c|}
\hline Genotype & HUL & MIL & HRR & KLBC & KBBC & KLAC & KBAC & $E / R$ & ASV & AROMA \\
\hline $\begin{array}{l}\text { Pusa } \\
1979-14-7- \\
33-99-226\end{array}$ & 77.45 & 67.63 & 55.42 & 8.68 & 1.69 & 19.04 & 2.35 & 2.19 & 7 & 3 \\
\hline PB $1121^{\#}$ & 78.15 & 69.70 & 55.80 & 8.76 & 1.68 & 18.82 & 2.30 & 2.15 & 7 & 3 \\
\hline CD (0.05) & 3.41 & 3.99 & 3.27 & 0.31 & 0.09 & 0.78 & 0.08 & 0.08 & - & - \\
\hline \multicolumn{11}{|c|}{$\begin{array}{l}\text { *Significant at } 5 \% \text {; HUL: hulling recovery in percentage; MIL: milling recovery in percentage; HRR: head } \\
\text { rice recovery in percentage; KLBC: kernel length before cooking in mm; KBBC: kernel breadth before } \\
\text { cooking in mm; KLAC: kernel length after cooking in mm; KBAC: kernel breadth after cooking in mm; } \\
\text { E/R: kernel elongation ratio; ASV: alkali spreading value; AROMA: aroma score from panel test; }{ }^{\text {PPB }} \\
1121 \text { showed complete mortality after herbicide spray, the data of PB } 1121 \text { taken from the unsprayed } \\
\text { area is presented for the purpose of comparison. }\end{array}$} \\
\hline
\end{tabular}

Based on molecular analysis of badh2 locus, all the HT-NILs were confirmed to have badh2 allele with 8 bp deletion which is identical to PB 1121 (Fig. 9). In sensory evaluation, the HT-NILs were found to be strongly scented with an aroma score of 3 .

\section{Discussion}

Basmati rice of India attracts consumers worldwide due to its peerless grain and cooking quality characteristics and appealing aroma. Among the Basmati rice varieties developed in India, PB 1121 is considered as the hallmark of Basmati owing to its exceptional KLAC (20 to $25 \mathrm{~mm}$ ) and high volume expansion upon cooking ( $>4$ times) (Singh et al. 2018). Basmati rice is protected under Geographical Indications (GI) for cultivation in seven states of north-western India where rice is primarily cultivated under transplanted conditions. However, due to the limited availability of labor on time, high transplanting cost and depleting water table, there is a need to shift rice cultivation to DSR. Although DSR is a potential technology, the response of farmers for its adoption has been lukewarm owing to heavy weed infestation under DSR. Herbicide tolerant rice varieties provide a potential alternative for effective weed management under DSR.

MABB has several advantages over conventional breeding and has been successfully deployed for improving elite rice varieties for resistance to biotic stresses such as bacterial blight and blast (Joseph et al. 2004; Gopalakrishnan et al. 2008; Singh et al. 2012; Singh V.K. et al. 2012; Singh V.K. et al. 2013; Khanna et al. 2015; Ellur et al. 2016a, 2016b), and abiotic stresses such as salinity tolerance (Babu et al. 2017; Singh et al. 2018a) which it has brought a paradigm shift in Basmati rice breeding (Singh et al.2011).

In this study, we report the transfer of herbicide tolerance trait from Robin into the genetic background of PB 1121 through MABB. Robin is an EMS induced mutant of an upland drought tolerant rice variety N22, which possess tall plant stature, short grains and lacks aroma (Shoba et al. 2017). Using poor grain quality DP to transfer HT trait into the genetic background of high quality Basmati rice variety PB 1121, is 
a challenging task especially for the recovery of exquisite grain and cooking quality of this Basmati rice variety in the improved HT-NILs. Foreground selection together with background and phenotypic selection led to precise transfer of mutant $A H A S$ gene for herbicide tolerance as well as accelerated the RPG recovery to an extent of 98.66 to $99.55 \%$ with four backcross generations. The complete recovery of RPG in mutant AHAS gene carrier chromosome as well as rest of chromosome was achieved except chromosomes 8 and 11, which retained some residual donor fragment (Fig. 3). Using the SSR markers for background analysis generally target the non-coding and heterochromatic regions and hence could not quantify the recovery of functional part of the genome. Therefore, background selection was coupled with phenotypic selection for RPP which helped in speeding the process of reconstruction of RPP as it entails the indirect selection for functionally expressed part of the genome (Ellur et al. 2016a).

PB 1121 HT-NILs were at par with PB 1121 for agro-morphological, grain and cooking quality traits, while exhibiting herbicide tolerance similar to Robin. This was possible due to stringent phenotypic selection for agro-morphological traits, grain and cooking quality traits for RP PB 1121 phenotype carried out in each of the backcross generations. The significance of phenotypic selection with background selection in the development of NILs with maximum RPG and RPP recovery has also been earlier demonstrated (Ellur et al. 2016b; Babu et al. 2017). Three NILs, Pusa 1979-14-7-33-99-15, Pusa 1979-14-7-33-99-10 and Pusa 1979-14-7-33-99-66 were significantly superior in yield, grain and cooking quality as compared to PB 1121 indicating the effectiveness of augmenting rigorous phenotypic selection for the cooking quality traits along with background selection.

Pleasant aroma is an essential trait of Basmati rice, which is primarily governed by a recessive gene badh2 located on chromosome 8. The accumulation of 2-acetyl-1-pyrroline (2-AP) in aromatic rice is explained by the loss of function mutations in the badh2 gene (Bradbury et al. 2005; Chen et al. 2008). All the PB 1121 HT-NILs and the recurrent parent PB 1121 were found to carry an 8 bp deletion corresponding to the aromatic allele for the production of 2-AP (Fig. 9).

AHAS is an enzyme which catalyzes two reactions for the synthesis of branched chain amino acids namely, valine, leucine, and isoleucine (Singh and Shaner 1995). Condensation of two pyruvate molecules forms 2-acetolactate which leads to the formation of valine and leucine. While for isoleucine biosynthesis, 2-acetohydroxybutyrate is synthesized from pyruvate and 2-ketobutyrate (Zhou et al. 2007). AHASinhibiting herbicides block the substrate access channel in the AHAS enzyme by binding to it and elicit deficiency of branched-chain amino acids (Garcia et al. 2017). The resulting decrease of protein synthesis slows down cell division thus leading to growth difficulties in plants (Yu et al. 2014). However, the mutations within the AHAS gene results in altered AHAS enzyme which confers resistance to the AHAS inhibiting herbicides (Tranel et al. 2002; Duggleby et al. 2000; Christoffers et al. 2006). The entire PB 1121 HT-NILs carrying mutated AHAS gene displayed tolerance to Imazethapyr herbicide when applied @ $2.5 \mathrm{ml} /$ liter with no significant difference in the yield performance, grain and cooking quality traits when compared to HT-NILs under unsprayed conditions. This indicates the effectiveness of mutant AHAS gene to overcome the adverse effect of herbicide Imazethapyr. 
In all, the present study reports successful development of non-GM HT NILs in the genetic background of popular Basmati rice variety PB 1121 by introgression of mutated $A H A S$ allele using MABB program. This is the first report of the development of HT rice in India. The PB $1121 \mathrm{HT}$-NILs are being evaluated in the National Basmati Trials for their subsequent release as commercial varieties. These NILs will help the farmers in adopting DSR in Basmati rice production which would help in economizing the rice production.

\section{Abbreviations}

DSR: Direct-seeded rice; HT: Herbicide tolerant; MABB: Marker assisted backcross breeding; AHAS:

Acetohydroxy acid synthase; PB: Pusa Basmati; DP: Donor parent; RP: Recipient parent; NIL: Near-isogenic line; RPP: Recurrent parent phenome; RPG: Recurrent parent genome; SSR: Simple sequence repeat; $A L S$ : Acetolactate synthase; EMS: Ethyl methane sulfonate; 2-AP: 2-acetyl-1-pyrroline; CD: Critical difference.

\section{Declarations}

\section{Ethics approval and consent to participate}

Not applicable.

\section{Consent for publication}

Not applicable.

\section{Availability of data and material}

All relevant data are provided as Tables within the paper and in the Supporting Information files.

\section{Competing interests}

The authors declare that they have no competing interests.

\section{Funding}

The research work supported grants by the Department of Biotechnology, Ministry of Science and Technology, Government of India, through the network project on "Maintenance, Characterization and use of EMS mutants of Upland Variety Nagina 22 for Functional Genomics in Rice-Phase-II" (BT/PR 10787/AGIII/103/883/2014).

\section{Authors Contributions}


The study is part of the Ph.D. thesis research of the first author. N.G. performed the experiments and prepared the manuscript; N.G., A.K.Y. conducted herbicide phenotypic screening; A.K.Y., R.K.E. did the statistical analysis; G.K.S., P.K.B., H.B, K.K.V., C.V., A.M.V.S. and N.M. guided field experiments; A.K., R.K.E. reviewed the manuscript; N.K.S., T.M., supervised the project; A.K.S:, G.K.S. conceptualized and supervised the project, edited and finalized the manuscript. All the authors have read and approved the final manuscript.

\section{Acknowledgments}

The senior author acknowledges the help rendered by the technical and supporting staff of the rice Genetics, Division of Genetics, for field work.

\section{References}

1. Amarawathi Y, Singh R, Singh AK, Singh VP, Mohapatra T, Sharma TR, Singh NK (2008) Mapping of quantitative trait loci for basmati quality traits in rice (Oryza sativa L.). Mol Breed 21(1):49-65

2. Anderson PC, Georgeson M (1989) Herbicide-tolerant mutants of corn. Genome 31(2):994-999

3. Babu NN, Krishnan SG, Vinod KK, Krishnamurthy SL, Singh VK, Singh MP, Singh R, Ellur RK, Rai V, Bollinedi H, Bhowmick PK (2017) Marker aided incorporation of Saltol, a major QTL associated with seedling stage salt tolerance, into Oryza sativa 'Pusa basmati 1121'. Front in plant sci 8:41

4. Bradbury LM, Fitzgerald TL, Henry RJ, Jin Q, Waters DL (2005) The gene for fragrance in rice. Plant biotech journal 3(3):363-370

5. Chen S, Xu CG, Lin XH, Zhang Q (2001) Improving bacterial blight resistance of ' 6078 ', an elite restorer line of hybrid rice, by molecular marker-assisted selection. Plant Breed 120(2):133-137

6. Doyle JDNA, Protocols for, Plants (1991) In: Hewitt G.M., Johnston A.W.B., Young J.P.W. (eds) Molecular Techniques in Taxonomy. NATO ASI Series (Series H: Cell Biology), vol. 57. Springer, Berlin, Heidelberg

7. Duggleby RG, Pang SS (2000) Acetohydroxyacid synthase. BMB Reports 33(1):1-36

8. Ellur RK, Khanna A, Gopala Krishnan S, Bhowmick PK, Vinod KK, Nagarajan M, Mondal KK, Singh NK, Singh K, Prabhu KV, Singh AK (2016b) Marker-aided incorporation of Xa38, a novel bacterial blight resistance gene, in PB 1121 and comparison of its resistance Spectrum with $x a 13+X a 21$. Sci Rep $6(1): 1-8$

9. Ellur RK, Khanna A, Yadav A, Pathania S, Rajashekara H, Singh VK, Gopala Krishnan S, Bhowmick PK, Nagarajan M, Vinod KK, Prakash G, Mondal KK, Singh NK, Prabhu KV, Singh AK (2016b) Improvement of basmati rice varieties for resistance to blast and bacterial blight diseases using marker assisted backcross breeding. Plant Sci 242:330-341

10. Garcia MD, Nouwens A, Lonhienne TG, Guddat LW (2017) Comprehensive understanding of acetohydroxyacid synthase inhibition by different herbicide families. Proc of the Nat Aca of Sci 114(7):E1091-E1100

Page $15 / 25$ 
11. Gopalakrishnan S, Sharma RK, Anand Rajkumar K, Joseph M, Singh VP, Singh AK, Bhat KV, Singh NK, Mohapatra T (2008) Integrating marker assisted background analysis with foreground selection for identification of superior bacterial blight resistant recombinants in Basmati rice. Plant Breeding 127(2):131-139

12. IRRI, CropStat 7.2 (2014) Biometrics and Breeding Informatics. PBGB Division, International Rice Research Institute, Los Baños

13. Joseph M, Gopalakrishnan S, Sharma RK, Singh VP, Singh AK, Singh NK, Mohapatra T (2004) Combining bacterial blight resistance and Basmati quality characteristics by phenotypic and molecular marker-assisted selection in rice. Mol Breeding 13(4):377-387

14. Khanna A, Sharma V, Ellur RK, Shikari AB, Krishnan SG, Singh UD, Prakash G, Sharma TR, Rathour R, Variar M, Prashanthi SK (2015) Development and evaluation of near-isogenic lines for major blast resistance gene (s) in Basmati rice. Theoretical App Gen 128(7):1243-1259

15. Little RR (1958) Differential effect of dilute alkali on 25 varieties of milled white rice. Cereal Chem 35:111-126

16. Christoffers MJ, Nandula VK, Howatt KA, Wehking TR (2006) Target-site resistance to acetolactate synthase inhibitors in wild mustard (Sinapis arvensis). Weed science 54(2):191-197

17. Pathak H, Tewari AN, Sankhyan S, Dubey DS, Mina U, Singh VK, Jain N (2011) Direct-seeded rice: potential, performance and problems-Areview. Current Adv in Agri Sci 3(2):77-88

18. Piao Z, Wang W, Wei Y, Zonta F, Wan C, Bai J, Wu S, Wang X, Fang J (2018) Characterization of an acetohydroxy acid synthase mutant conferring tolerance to imidazolinone herbicides in rice (Oryza sativa). Planta 247(3):693-703

19. Powles SB, Yu Q (2010) Evolution in action: plants resistant to herbicides. Annu Rev Plant Biol 61:317-347

20. Rao AN, Wani SP, Ramesha M, Ladha JK (2015) Weeds and weed management of rice in Karnataka state, India. Weed Technol 29(1):1-7

21. Rohlf FJ (1998) Numerical taxonomy and multivariate analysis system (NTSYSpc): Ver. 2.0. Exeter Publication, Setauket

22. Shoba D, Raveendran M, Manonmani S, Utharasu S, Dhivyapriya D, Subhasini G, Ramchandar S, Valarmathi R, Grover N, Krishnan SG, Singh AK (2017) Development and genetic characterization of a novel herbicide (Imazethapyr) tolerant mutant in rice (Oryza sativa L.) 10(1):1-12

23. Singh A, Singh VK, Singh SP, Pandian RT, Ellur RK, Singh D, Bhowmick PK, Gopala Krishnan S, Nagarajan M, Vinod KK, Singh UD (2012) Molecular breeding for the development of multiple disease resistance in Basmati rice. AoB Plants 2012

24. Singh AK, Gopalakrishnan S, Singh VP, Prabhu KV, Mohapatra T, Singh NK, Sharma TR, Nagarajan M, Vinod KK, Singh D, Singh UD (2011) Marker assisted selection: a paradigm shift in Basmati breeding. Indian J Genet 71(2):120

25. Singh BK, Shaner DL (1995) Biosynthesis of branched chain amino acids: From test tube to field. Plant Cell 7(7):935 
26. Singh VK, Singh A, Singh SP, Ellur RK, Choudhary V, Sarkel S, Singh D, Krishnan SG, Nagarajan M, Vinod KK, Singh UD (2012) Incorporation of blast resistance into "PRR78", an elite Basmati rice restorer line, through marker assisted backcross breeding. Field Crops Res 128:8-16

27. Singh VK, Singh A, Singh SP, Ellur RK, Singh D, Gopala Krishnan S, Bhowmick PK, Nagarajan M, Vinod KK, Singh UD, Mohapatra T (2013) Marker-assisted simultaneous but stepwise backcross breeding for pyramiding blast resistance genes Piz5 and Pi54 into an elite Basmati rice restorer line 'PRR 78'. Plant Breeding 132(5):486-495

28. Singh VK, Singh BD, Kumar A, Maurya S, Krishnan SG, Vinod KK, Singh MP, Ellur RK, Bhowmick PK, Singh AK (2018a) Marker-assisted introgression of Saltol QTL enhances seedling stage salt tolerance in the rice variety "Pusa Basmati 1". International J of gen 2018

29. Singh V, Singh AK, Mohapatra T, Gopala KS, Ellur RK (2018) Pusa Basmati 1121-a rice variety with exceptional kernel elongation and volume expansion after cooking. Rice 11(1):19

30. Sood BC, Siddiq EA (1978) A rapid technique for scent determination in rice [India]. Indian Journal of Genet Plant Breeding 38:2268-2271

31. Tan S, Evans RR, Dahmer ML, Singh BK, Shaner DL (2005) Imidazolinone-tolerant crops: history, current status and future. Pest Management Sci: Formerly Pesticide Science 61(3):246-257

32. Tan S, Evans R, Singh B (2006) Herbicidal inhibitors of amino acid biosynthesis and herbicide-tolerant crops. Amino Acids 30(2):195-204

33. Tranel PJ, Wright TR (2002) Resistance of weeds to ALS-inhibiting herbicides: what have we learned? Weed Sci 50(6):700-712

34. Van Berloo R (1999) Computer note. GGT: software for the display of graphical genotypes. J of Heredity 90(2):328-329

35. Yu Q, Powles SB (2014) Resistance to AHAS inhibitor herbicides: current understanding. Pest manag sci 70(9):1340-1350

36. Zhou Q, Liu W, Zhang Y, Liu KK (2007) Action mechanisms of acetolactate synthase-inhibiting herbicides. Pest bioc phys 89(2):89-96

\section{Figures}




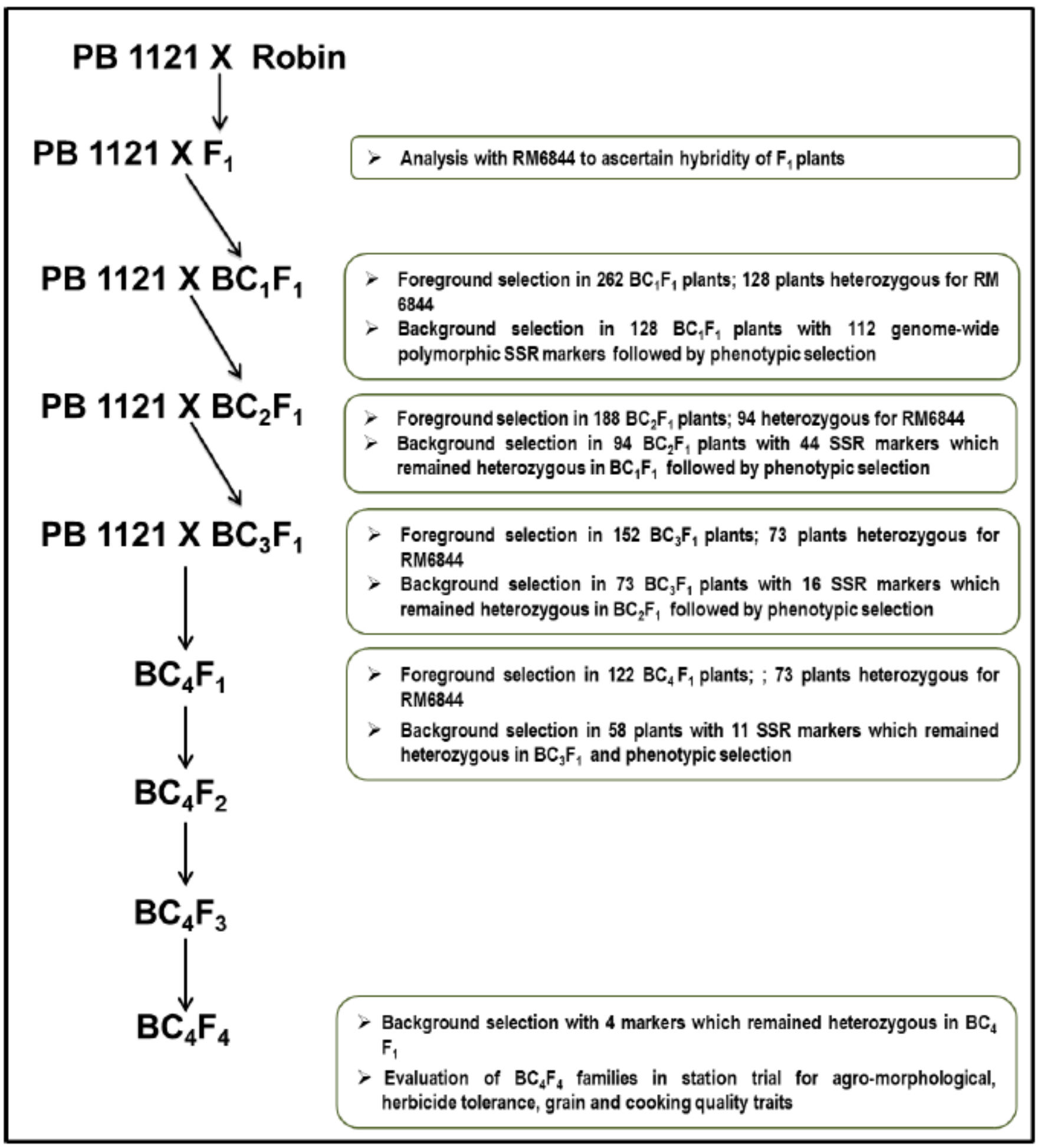

Figure 1

Marker aided backcross breeding strategy used for transferring the herbicide tolerance trait into PB 1121. 


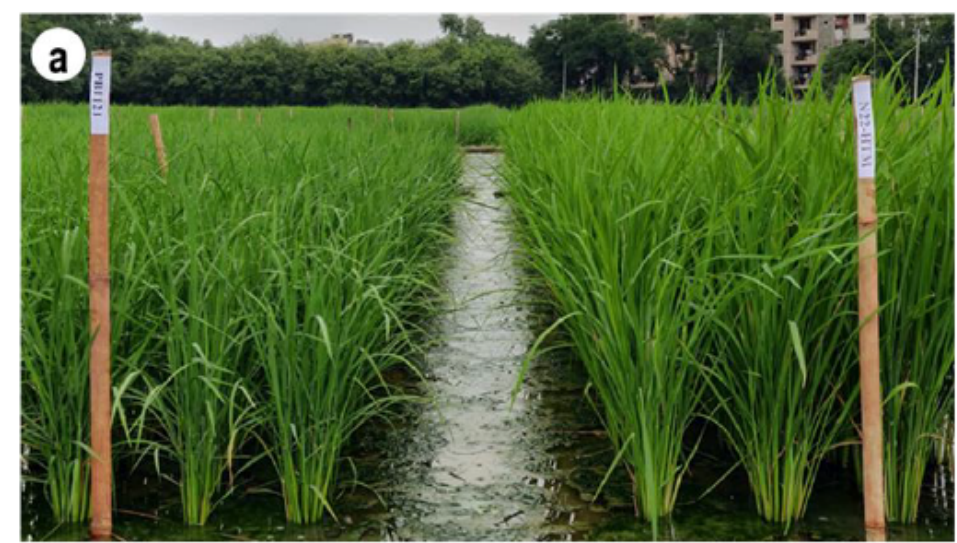

PB 1121
Robin

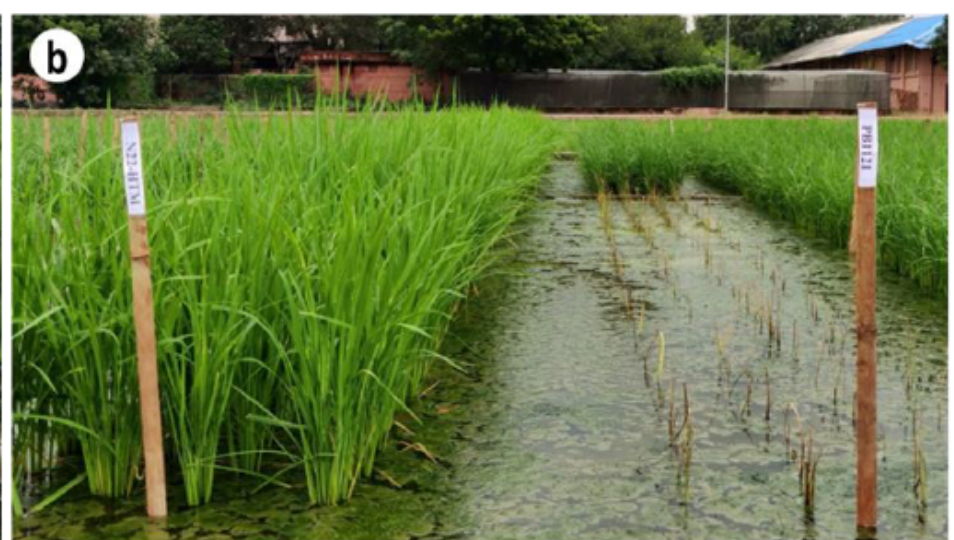

Robin

PB 1121

Figure 2

Phenotypic evaluation of donor parent, "Robin” and recurrent parent, "PB 1121" for Imazethapyr herbicide tolerance @ concentration of 2.5 ml/liter, (a) Unsprayed, (b) Sprayed.

PB 1121

Robin

Pusa 1979-14-7-33-99-8

Pusa 1979-14-7-33-99-10

Pusa 1979-14-7-33-99-15

Pusa 1979-14-7-33-99-34

Pusa 1979-14-7-33-99-56

Pusa 1979-14-7-33-99-66

Pusa 1979-14-7-33-99-87

Pusa 1979-14-7-33-99-101

Pusa 1979-14-7-33-99-143

Pusa 1979-14-7-33-99-166

Pusa 1979-14-7-33-99-182

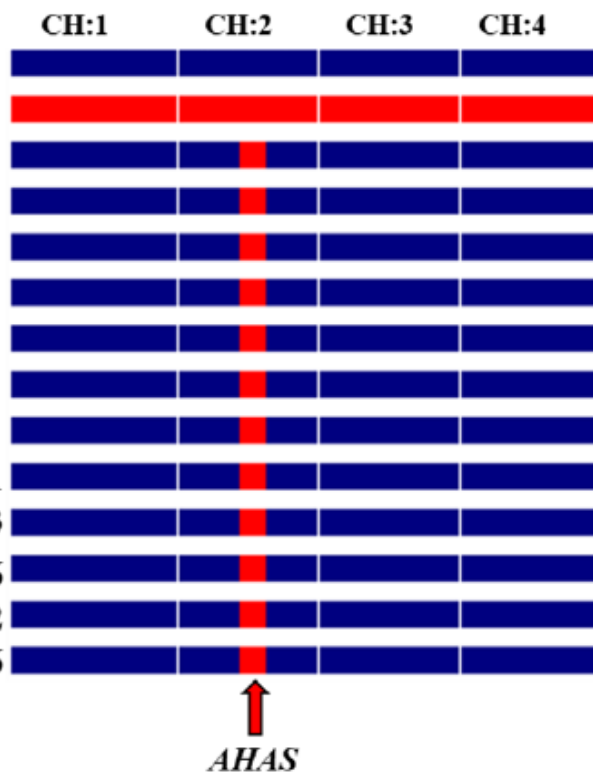

CH:5 CH:6

CH:7 CH:8 CH:9 CH:10 CH:11 CH:12

Pusa 1979-14-7-33-99-226

Figure 3

Graphical representation of PB 1121 HT-NILs carrying AHAS gene showing the extent of recurrent parent genome (RPG) recovery. $\mathrm{CH}$ : chromosome. 


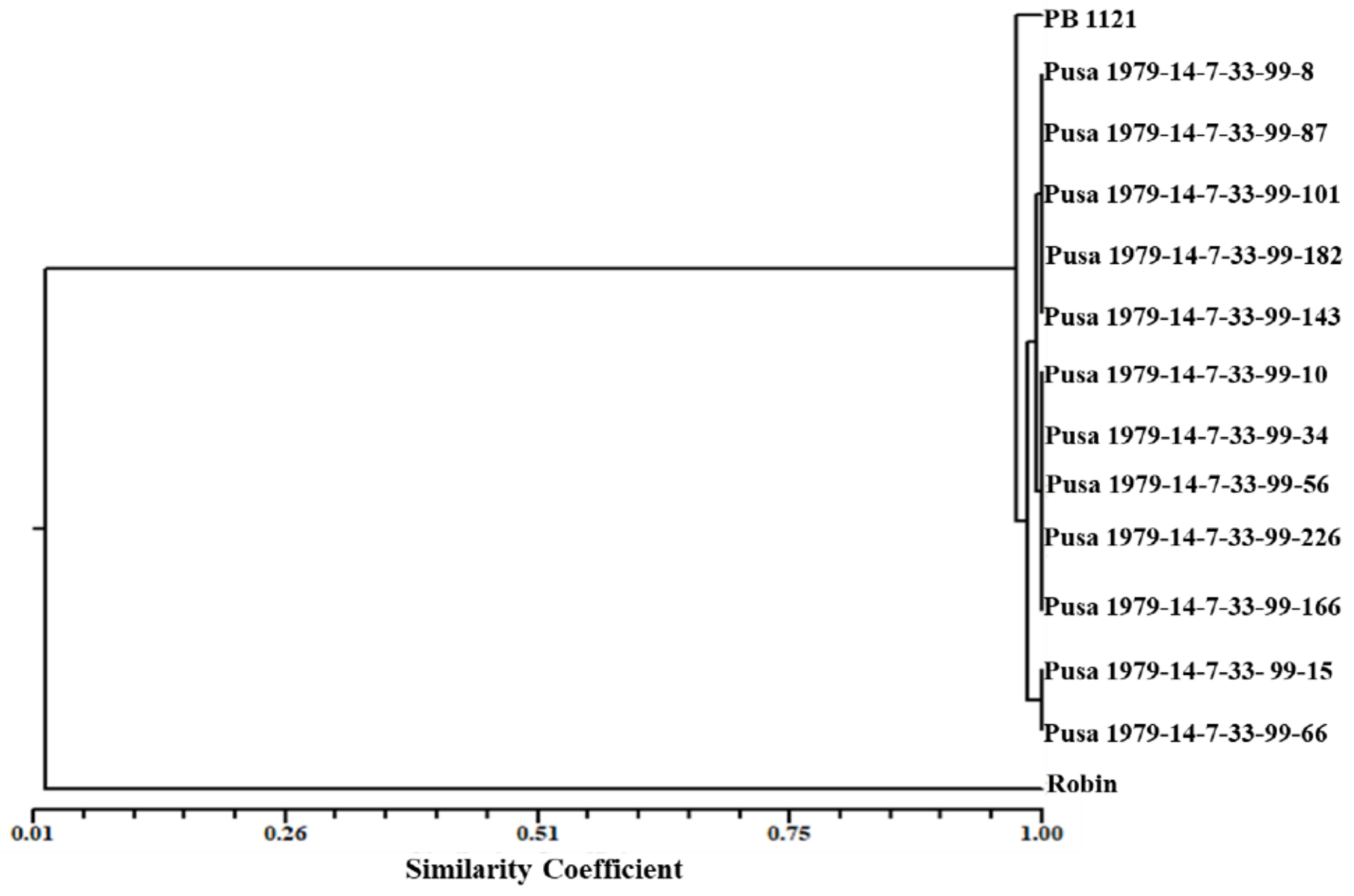

Figure 4

Dendrogram showing the genetic relationship among different PB 1121 HT-NILs in BC4F4 generation and their parents, PB 1121 and Robin based on 112 polymorphic SSR markers 

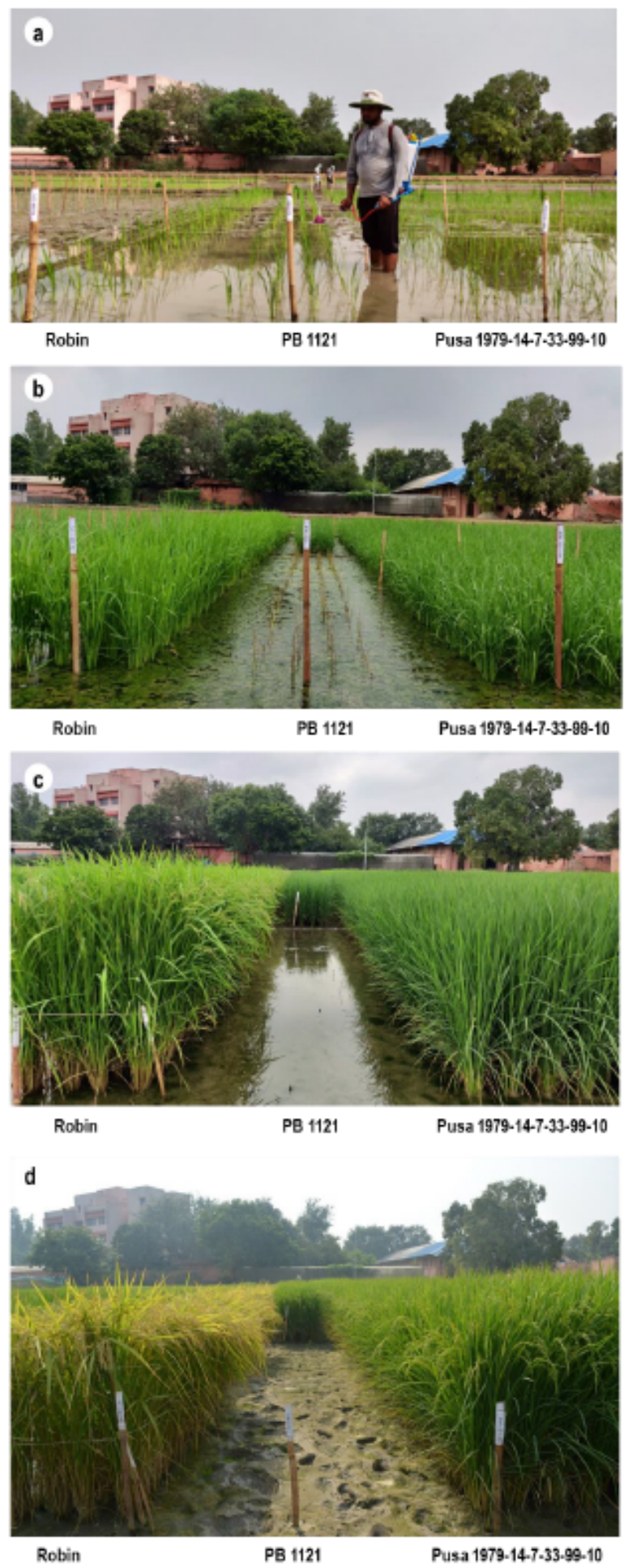

\section{Figure 5}

Phenotypic screening of PB 1121-HT NILs along with Recurrent Parent (RP), PB 1121 and Donor Parent, Robin for tolerance to the herbicide, Imazethapyr, (a) application of Imazethapyr @ $2.5 \mathrm{ml} /$ liter after 10 days of transplanting, (b) 20 days after herbicide spray showing that complete death of RP, (c) 60 days after herbicide spray, (d) 90 days after herbicide spray. 

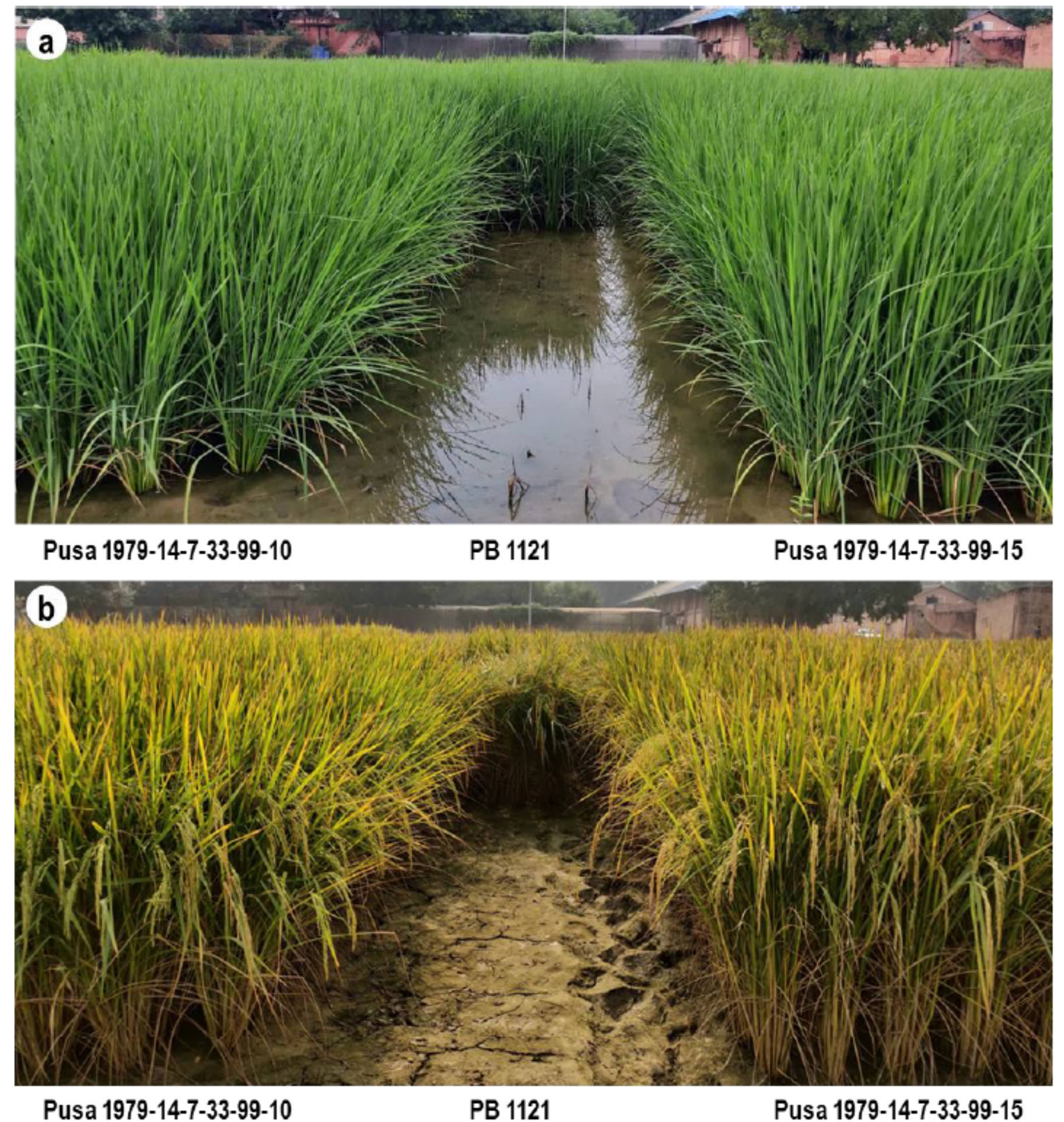

Figure 6

Field view of the PB 1121 HT-NILs at (a) booting and (b) maturity. 


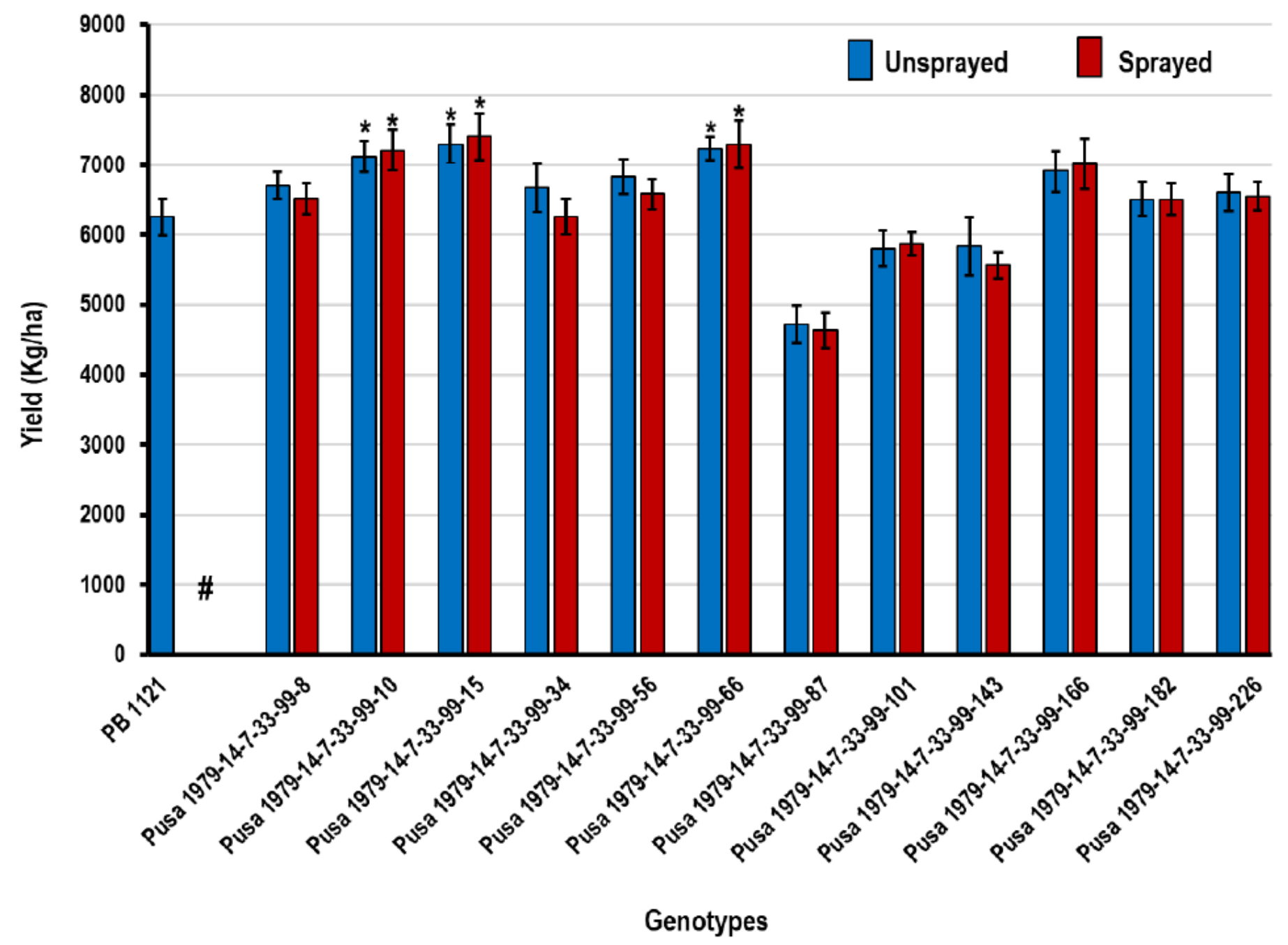

Figure 7

Comparison of yield $(\mathrm{kg} / \mathrm{ha}$ ) between PB 1121 HT-NILs and their parents in unsprayed and herbicide sprayed condition; \#PB 1121 seedling did not survive Imazethapyr spray; *Significantly superior to the recurrent parent, PB 1121. 


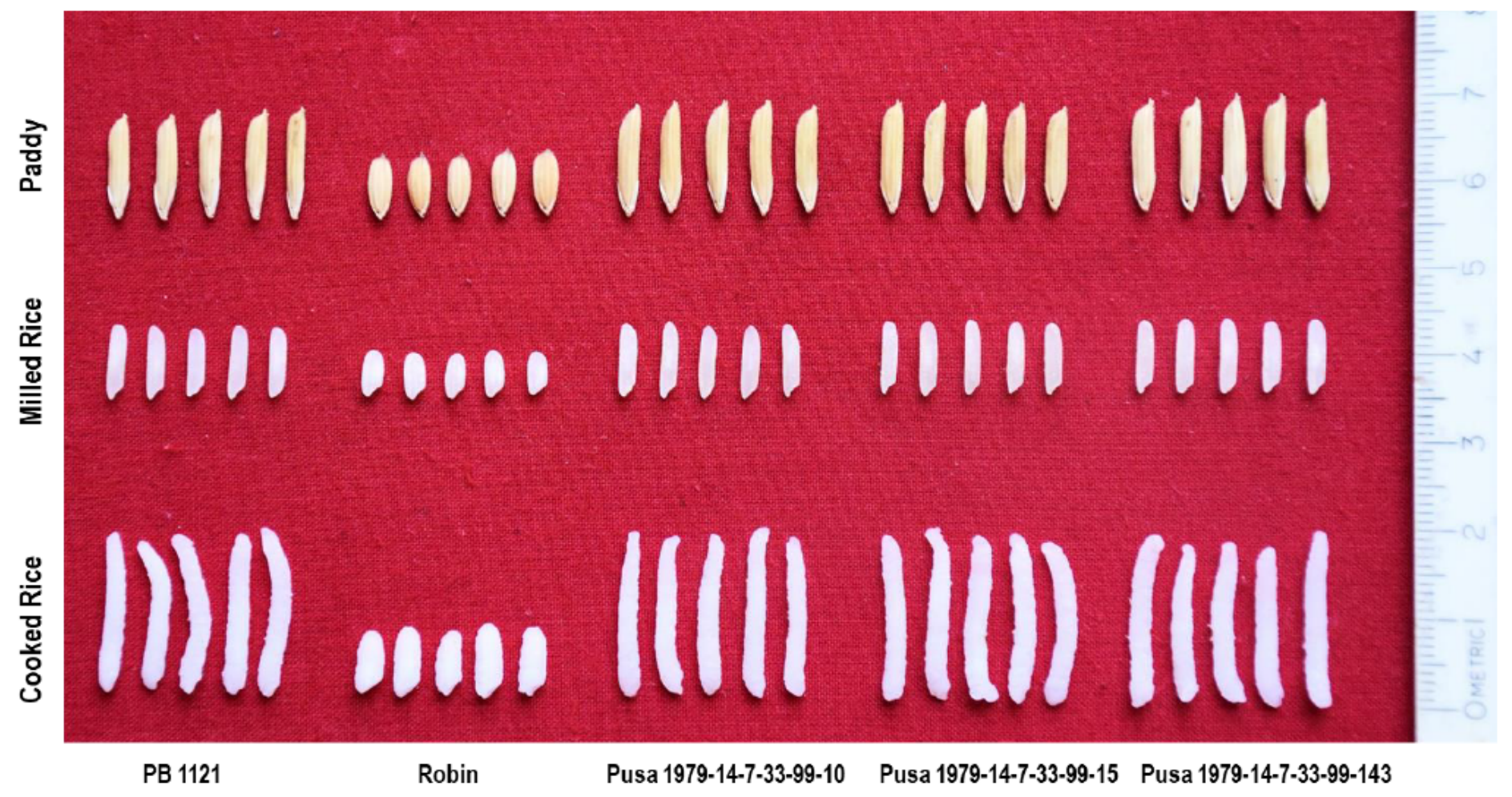

Figure 8

Grain and cooking quality of selected PB 1121 HT-NILs and their parents, PB 1121 and Robin.

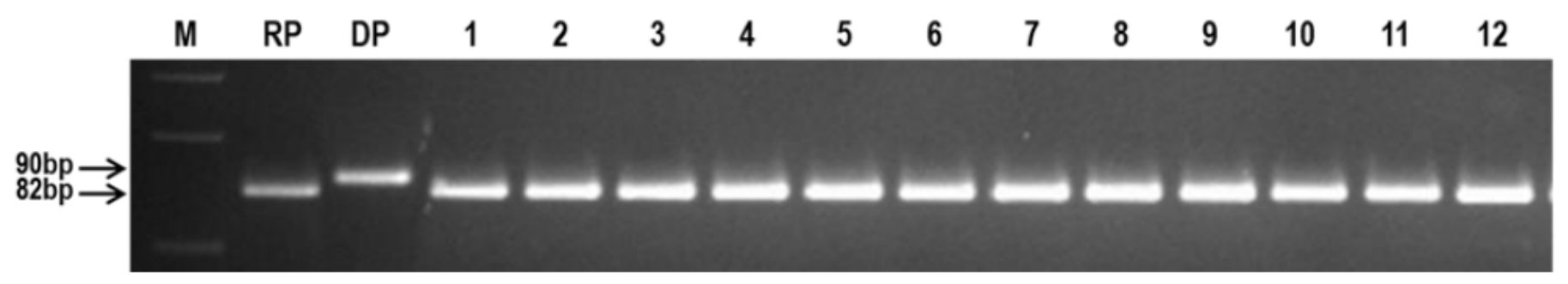

Figure 9

A representative image showing the amplification profile of the marker, "nksbad2" based on 8bp deletion in badh2 in the PB 1121 HT-NILs along with recurrent parent (RP), PB 1121 and the non-aromatic donor parent (DP) Robin , 1-12: PB 1121 HT-NILs, Pusa 1979-14-7-33-99-8, Pusa 1979-14-7-33-99-10, Pusa 197914-7-33- 99-15, Pusa 1979-14-7-33-99-34, Pusa 1979-14-7-33-99-56, Pusa 1979-14-7-33-99-66, Pusa 197914-7-33-99-87, Pusa 1979-14-7-33-99-101, Pusa 1979-14-7-33-99-143, Pusa 1979-14-7-33-99-166, Pusa 1979-14-7-33-99-182 and Pusa 1979-14-7-33-99-226

\section{Supplementary Files}


This is a list of supplementary files associated with this preprint. Click to download.

- AdditionalTables.docx 